\title{
TEACHING LANGUAGE TO THE SPECIAL CHILDREN: CHALLENGES AND POSSIBILITIES
}

\author{
Quazi Farzana Yesmin \\ Lecturer in English, \\ City University, \\ Dhaka, \\ Bangladesh
}

\author{
Sifat Ullah \\ Teacher, \\ HEED International School, \\ Dhaka, \\ Bangladesh
}

\author{
Mohammad Ehsanul Islam Khan \\ Lecturer, \\ Department of English, \\ Manarat International University, \\ Dhaka, Bangladesh
}

Article DOI: https://doi.org/10.36713/epra4479

\begin{abstract}
Since communicating people is one of the first and foremost obstacles to autistic children, it is a basic need for them to get vigilant and appropriate nurture for language acquisition. Moreover, to develop the language skills of special children appropriately, it is essential to ensure effective language teaching. The primary objective of this study was to identify the challenges that the teachers face in the class and to bring out the possibilities of teaching the mother tongue to the special children as a part of special education. As language learning is the leading step of special education, the study aims to contribute to the field by pointing out the challenges and the possibilities. The study was conducted by collecting data from three different schools of special children by following a qualitative method. The findings revealed that inadequate understanding, proper classroom facilities, lack of awareness and insufficient language training created a great challenge for the teachers in teaching the language to the special children. The study also exposed that special training, a well-decorated classroom, regular speech therapy, and change of outlook minimized the challenges and made language teaching more effective.
\end{abstract}

KEYWORDS: Autism Spectrum Disorder (ASD), Special Education Needs (SEN), Communication, Language Proficiency

\section{INTRODUCTION}

Autism is not a disease; it is a lifelong developmental disability. Autism is such a disability that makes a child specialist with a unique and different specialty. Autism and 'autism spectrum disorder' both are general terms for the people who have disorders of brain development. Children with Autism Spectrum Disorder (hereafter, ASD) need proper mind development through special education to learn. This paper was conducted on children with special educational needs (SEN) who are suffering from ASD and have significant language challenges from an early age. Moreover, as the oral expression has become the first and foremost way of communication, it is very essential to bring up special children in a special communicative manner of learning. To ensure the rights of education to the disabled children equally, there is no other alternative way to make them skilled first in language learning, because, a major characteristic of the autistic population is the abnormal development of speech and language (Ritvo \& Freeman, 1978; Rutter, 1978). Hence, their mental growth and the skill of communicating people are seemed to be delayed for a lack of proper verbalization.

Since communicating people is the predominant obstacle to autistic children, it is a basic need for them to get careful and proper nurture for language acquisition. Moreover, to develop the language skills of special children appropriately, it is essential to ensure effective language teaching to them. The goal of this study is to identify the 
challenges that the teacher faces in the class and to bring out the possibilities of teaching the mother tongue to the special children as a part of special education. As language learning is the leading step of special education, the study aims to contribute to the field by pointing out the challenges and the possibilities with the belief of making a bridge between the special children and the mainstream children in society.

ASD is a lifelong developmental disorder that affects a child's communication and behavior. Children with ASD usually have significant language delays, challenges with communication and social functioning, and unusual behaviors and interests. They have poor eye-contact, poor socialization, poor communication, and poor attention. Although the symptoms can be diagnosed at any age, usually they tend to emerge between 2 and 3 years of age. ASD affects brain areas controlling language, social interaction, and language thoughts, (Bridgette, 2005). ASD "is a complex developmental disability that essentially affects the way a person communicates and relates to people," (Autism Working Group, 2002 , p. 1). "The term spectrum is used because the characteristics of the disorder occur along a continuum, with severe symptoms at one end and very mild behaviors at the other," (Wills, 2009, p. 81 ). Dr. Leo Kanner in the 1940s was the first to identify Autism in the US (Furniss, 2008). Furniss (2008), states though at first psychopathology was thought to be its cause but now it is thought to have neurological origins.

'Special Educational Needs' (SEN) is a term that refers to children who have challenges with learning. Due to having learning problems or disabilities, children with special educational needs find their learning harder for them to learn than most other children of the same age. They may have problems with schoolwork, language learning, communication, or behavior.

\section{OBJECTIVES}

Since the children with ASD have the challenges in language acquisition, teaching language to these special children is undoubtedly quite challenging. Hence, they are taught through the special education system. So, to create a new dimension in acquiring education, it is very essential to bring out the challenges that the instructors face in teaching languages to special children. Considering all the facts, the research was conducted based on two objectives. They are:

i) to find out the challenges in teaching languages to the special children

ii) to point out the possibilities in teaching languages to the special children

\section{LITERATURE REVIEW}

All the elements related to the effectiveness of the process of teaching productive skills are given here for getting a better understanding of the topic. These helped in completing the research systematically. Moreover, a deeper understanding of the process of educating a child with ASD both inhome and outside the country also helped to better realize the present scenario of Bangladesh where special education is essential for children with ASD for their fast-psychological development.

Akhter (2015) attempted to take a deeper look at the teaching process of productive skills concerning Autistic children mainly children with Asperger Syndrome and measure its effectiveness in Bangladesh. She mentioned that the country was quite backward in the field of special education. The researcher found that insufficient certified teacher and speech therapist, lack of implementation of technological aid, early intervention, no distinct curriculum, lack of funding and benefits, unawareness of parents and society are vital reasons for its ineffectiveness. She also found that parents are not conscious about their role regarding their children's development hence they are not active in their development and teaching process. Suitable environments and settings of the school are other factors obstructing their progress. She recommended that more effort and promotion is needed in this field to raise the consciousness of cities around the country. Propaganda should be made to raise the consciousness of the citizens towards these children so that people do not hesitate in conversing with them and behave appropriately this will help in their developmental process consequently in their teaching process as well.

Wilson (2010) states that during the year 1950s and 60s, schools for special children emerged in different parts of the country some established by the parents, frustrated due to the lack of services offered for children with autism. Now almost "two dozen schools" are serving children with ASD with therapists and special teachers to help these special children cope with their disorder with ASD across Massachusetts, with dedicated teachers and therapists working to help these kids cope with their disorder and above all educate and teach them to function in this world (p.22).

Padurean (2014) discussed the most appropriate methods and techniques used for Teaching L1 to children with special educational needs. She also mentioned that the teachers can teach regular children simultaneously with mainstream children, though these were reluctant regarding the education of children with special educational needs in mainstream education. She also found that language can be taught to children with SEN without placing them in special schools. Though certain teachers believe that a foreign language should not be 
taught to children who still have difficulties with their mother tongue, it is a bad decision. Learning a new language opens their minds, helps them create cognitive relations, organizes their mind, and brings satisfaction. Teachers should adapt their lessons to children with SEN, should engage them in classroom activities, and use interactive methods. These methods are beneficial for regular students too because they are challenging, favors communication and interaction.

Sultana, Ferdous, and Munir (2002) mentioned that Rights to education should be applied to both disabled and non-disabled children. To reach the goal of "Education for All", an inclusive school system has been observed in Bangladesh. The study described the efforts made by the Bangladesh Protibondhi Foundation and the effectiveness of inclusive schools as a pilot scheme is also evaluated. They have found that most of the parents of disabled students opined that the negative attitude of the society of excluding their children from mainstream education formed the biggest barrier to language education like mainstream education. But the teachers expressed that the inclusive schools made the disabled children gain independence and become socially relaxed with the environment. Their observation was that both the disabled and nondisabled students were improving satisfactorily. Severely disabled children however required much individual attention, yet they also gradually became part of the inclusion group.

The study of Randi, Elina and Tina (2010) examined what made reading for understanding especially challenging for children on the autism spectrum. They reviewed reading comprehension interventions for children on the spectrum. The paper first summarized the research on reading comprehension with a focus on the cognitive skills and processes that are involved in gaining meaning from text and then reviewed studies of reading comprehension deficits in children on the spectrum. The paper concluded with a review of reading comprehension interventions for children on the spectrum. The children could especially benefit from interventions addressing particular cognitive processes, such as locating antecedent events, generating and answering questions, locating referents, and rereading to repair understanding.

\section{METHODOLOGY}

A qualitative method was used to measure the effectiveness of teaching language to children with ASD. Interview and classroom observation were used to bring out the result of the research questions. The interview was conducted encompassing subjective questions to a deeper insight. The qualitative method was used to get authentic data and finding an in-depth problem regarding the teaching process of children with ASD.

\subsection{Subject}

The study was conducted from three different schools of special children located in Dhaka city by following a qualitative method. This method mainly includes interviews of six teachers where two were male and four teachers were female from the selected schools. Apart from the teacher, data was collected from one speech and language therapist. Data was also collected from classroom observation. Three classes were observed from three special schools.

\subsection{Instrumentation}

The research instruments employed to collect data for this study were interviews and class observation. The interview was conducted in an informal setting with six teachers in their school premises. And the speech and language therapist were interviewed in his chamber in a formal setting. They had to answer seven questions and justify their claim.

However, enough time was given by the teachers though, they were all in a rush. A mobile phone was used to record the interview taking the permission of interviewees. Together with the interview, the researchers used class observation to see how the teachers carried out classes with special children, how the teachers handled them, and what problems the teachers encountered in language teaching. The researchers observed three classes, one period for each class.

\subsection{Data Analysis}

After obtaining the data through interviews and class observation, the researchers need to point out how the gathered data is analyzed. The researchers used The Data Analysis Spiral which is proposed by Creswell (1998) that in this research as follows:

Data managing: In this first step, the researcher organizes the data gathered by using the techniques of collecting the data into folders then converts them into sentences.

Reading and memo writing: In the second step, the researchers read and write memos related to the field notes from the direct observation and transcription from the interview.

Describing, classifying, and interpreting: In this part, the researchers give a clear description of the data found in detail. Besides, the researcher classifies and chooses which data meet to the researcher's purposes in this research as well as interpret the data

Representing and visualizing: After the above three steps, the researcher displays the data found in terms of text.

\section{FINDINGS AND DISCUSSION}

The findings of the study are discussed in the following sections based on the objectives of the study. Firstly, the challenges that the teachers face in teaching language to the special children are 
discussed based on the responses from the interview and the class observation. Secondly, the possibilities are shown.

\subsection{Challenges}

Teaching special children is not like teaching regular students. Teachers usually face difficulties in teaching language to special children. The first challenge that the teachers face is communication. Most of the time teachers fail to communicate the children with ASD. One of the teachers said, "It is very difficult to get the verbal response from the children. It takes at least two to five months or sometimes up to one year to get a minimum response." From the class observation, it was also found that the teachers had to give more time and effort to get the students' attention for minimum communication. In most of the cases, teachers fail to understand what the children do want and what they do not want. So, inadequate understanding creates problems in communication in teaching language to special children.

The teachers mentioned some other basic challenges that they face at the beginning of handling a special student such as sitting habits. The children are unwilling to sit in a place properly. They don't want to sit in a fixed place for a certain time. They like to move and turn back and make noise and unnecessary sounds. Another problem the teachers mentioned is delayed coming. Some of the children come to school at a late age. As a speech therapist told, "Most of the parents can't identify that their child is born with special qualities and sometimes they do not want to agree that their child is special." As a result, most of the students are late in school. The children who come late in school are less responsive in the classroom. Moreover, from the response to the interview and the class observation, it is found that the non-cooperative attitude of the parents, lack of sufficient equipment, and proper language therapy for the students at the institutions for the special children are the major problems in teaching language to the special children.

In response to a question regarding the teaching facilities in the classroom, they mentioned that some facilities, for instance, modern technology, enough equipment, and skilled language therapist and educators should be provided to get a fruitful result in the students' language learning from such kind of special language learning classes. One of the teachers told, "Lack of regular special training for the teachers and the staff creates a big challenge to teach the special children."

Ahmed (2015) found that most of the teachers noted that speech and language therapy functioned with child for evaluating, diagnosis, providing specific and group therapy in order to child's speech, language and improvement of communication". The teachers of the current study also mentioned the similar idea and told that special training in teaching language to children with autism is quite important and essential for the teachers who are related to such a special teaching profession. They also emphasized on the implication of modern equipment in teaching language to special children. Hence, they all think the authority should take prompt action in arranging special training and providing the necessary equipment for the teachers. Moreover, they also expect the necessary steps and assistance from the government as well.

\subsection{Possibilities}

From the interview and class observation, the researchers have found some possibilities in the field of special-children language education. Teachers are able to communicate and interact with the special children in the classroom in some new and different manners. They use pre-verbal skills like using rhythm, variations of tone, eye-contact, and vocalization to communicate with the special students. Among the six teachers, everyone agreed that special language learning classes are important or would be more effective for the students in learning a language or be responsive in the language classroom rapidly. They added that special language classes are very fruitful for both the teachers and the students. According to the speech therapist, regular special classes with language therapy is needed to improve their language ability and their behavior. As she said, "If they (the special children) are given regular speech therapy, at least once in a week, and at the same time special language classes are held, it is possible to get the positive and fruitful result within a short time."

In answering the question regarding the possibilities, the teachers have informed that, in Bangladesh, educators who are willing to teach at a school of special children must have special training. They have also the opportunity to do a certificate course on Bachelor of Special Education (B.S.Ed.) from some government and non-government institutions in the country. Moreover, some national and international NGOs are also emerging with a helping hand to train up the teachers of special education. Most importantly the speech and language therapy activities can get success if the collaboration and patronage are functioning among the teachers, parents, administrators, psychotherapist, and the civic to comprehensive tutoring in school (De Boer, Pijl \& Minnaert, 2011).

\section{RECOMMENDATIONS}

Based on the findings and the profound discussion, the following suggestions could be considered for the advancement of teaching language to the special children by overcoming the challenges and utilizing the possibilities in a better way: 
- Changing our attitude to the autistic children

- Decorating the classrooms attractively to the students

- Arranging special training for both the teachers and the caregivers as Mader (2017) thought that the capable teachers with proper knowledge to teach special children is more serious now-a-days than before

- Arranging special language classes for the students

- $\quad$ Arranging of regular language therapy by a special language therapist

- Providing modern and essential tools for the language classes

- $\quad$ Recruiting expert teachers for conducting the language classes

- Regular counseling with the children

- Regular counseling with the parents

Moreover, regular moderation of authority is a must in the implementation of the above suggestions. Additionally, with the government and other nongovernment organizations' help, teaching language to the special children can be developed in many ways and can reach to success in developing the children's disabilities.

\section{CONCLUSION}

Education is a basic right to all. Children with ASD need special education to have proper brain development. Only special education with special care can bring out their latent talent. Relevantly, language is the first and foremost way of communication and since communication is the biggest problem for the children with ASD, focusing on the point, the study found that teachers have to face very crucial challenges in teaching language to the students which are certainly a very difficult task. Based on the interview question-answer and the analysis, the study indicates that the possibilities that already have been discussed can make a new era in ensuring the special education to the special children. The disabilities of these children which is a curse to them can be turned into a blessing by providing them quality education and language learning is the first step of that quality education. In this context, this is high time we should change our outlook towards the special children, we should take their responsibilities as an important part of our future days. The recommendations that the study mentioned also can play a vital role in the development of the present condition of teaching language to the special children in the Bangladesh context. In conclusion, it can be asserted that with a good combination and coordination among all, teaching language to the special children can be fruitful and effective.

\section{Acknowledgment}

The researchers are thankful to 'Hello-Teen Society' (govt. registration no. S-13170), an organization for education, research, and welfare for the overall support in terms of doing the study. However, the organization did not play any role to conduct the study but reviewed the complete project.

\section{REFERENCES}

1. Ahmed, T. (2015). Teacher's Perceptions about Speech \& Language Therapy Services in Inclusive Schools. Published Research Project for B.Sc. in Speech and Language Therapy, BHPI, CRP, University of Dhaka, Retrieved January 30, 2020 from http://library.crpbangladesh.org:8080/xmlui/bitstream/handle/123 456789/151/9.\%20Tusha\%20Ahmed.pdf?sequenc $e=1$ \&isAllowed $=y$

2. Akhter, R. (2015). Challenges facing in Teaching Language to the children with Autism. BA Thesis, BRAC University, Retrieved from http://123.49.46.157/handle/10361/4188.

3. Creswell, J. W. (1998). Qualitative inquiry and research design: Choosing among five traditions. London: Sage Publications.

4. De Boer, A., Pijl, S. J., \& Minnaert, A. (2011). Regular Primary School Teachers' Attitudes towards Inclusive Education: A Review of the Literature. International Journal of Inclusive Education, 15(3), 331-353.

5. Furniss, J.G. (2008). Celebrating the Art making of Children with Autism. Art Education, 61(5), 812, DOI: 10.1080/00043125.2008.11518990.

6. Mader, J. (2017). How Teacher Training Hinders Special-Needs Students. The Atlantic, Retrieved 20 Janury 2020 from https://www.theatlantic.com/education/archive/2 017/03/how-teacher-training-hinders-specialneeds-students/518286/

7. Padurean, A. (2014). Teaching English Language to Children with Special Educational Needs. Retrieved from https://www.researchgate.net/publication/301682 674.

8. Randi, J., Elena, T. N. \& Grigorenko, L. (2010). Teaching Children with Autism to Read for Meaning: Challenges and Possibilities. Journal of Autism and Developmental Disorders, 40(7), 890-902.

9. Z., Ferdous, S., \& Munir, S. (2002). From Special Education to Inclusive Education Moving from Seclusion to Inclusion. Asia \& Pacific Journal on Disability, 5(1), 1-15.

10. Wills, A.T. \& Gibbons, X. F. (2009). Commentary: Using Psychological Theory in Help-Seeking Research. Clinical Psychology, Science and Practice, 16(4), 440-444.

11. Wilson, D. T. (2010). Fifty Years of Information Behavior Research. Bulletin of the American Society for Information Science and Technology Banner, 36(3), DOI: https://doi.org/10.1002/ bult. 2010.1720360308. 